\title{
From Populist Developmentalism to Liberal Neodevelopmentalism:The Specificity and Historical Development of Brazilian Capital Accumulation
}

Nicolás Grinberg, National Scientific and Technical Research Council (Argentina) and

Institute for Advanced Social Studies, National University of San Martin (Argentina)

\begin{abstract}
This article analyzes the trajectory of Brazilian society between the time of populist developmentalism and the emergence of neodevelopmentalism. Challenging mainstream accounts, it argues that the various policy regimes consolidating throughout the period have been forms of realization of the autonomously regulated process of capital accumulation on a global scale. More concretely, it is claimed that Brazilian capitalism has developed under a specific form which sprung from its particular original subsumption in the international division of labor as producer of primary commodities; capital has accumulated there through the recovery of a portion of the local ground rent. This form of capital accumulation has come about through specific developmental patterns, state policies, and political processes. Analysis of the historical development of the Brazilian process of capital accumulation demonstrates the inherent unity among the various policy regimes.
\end{abstract}

$\mathrm{N}$ ot long ago, the Brazilian economy was at the center of several academic and policy-oriented debates, many of these focusing on its alleged "emerging power" status and on the processes-crucially, state actions-making this possible. ${ }^{1}$ Some authors attribute Brazil's economic recov-

1. See, e.g., C. Ban and M. Blyth, "The BRICs and the Washington Consensus: An Introduction," Review of International Political Economy 20 (2013): 241-55.

Critical Historical Studies (Spring 2016). ( 2016 by The University of Chicago. All rights reserved. $2326-4462 / 2016 / 0301-0003 \$ 10.00$ 
ery during the 2000s and its consolidation in the global scene to the neoliberal free-market reforms introduced in the 1990s and, supposedly, continued during the subsequent period. ${ }^{2}$ Others argue that it has been a consequence of the replacement of the neoliberal policy regime with a new developmentalist approach that repositions the state as an actor in national economic and social development. ${ }^{3}$ Yet others claim that the policy regime associated with Brazil's emerging power status has resulted from a hybrid or eclectic combination of neoliberal (financial and monetary) and neodevelopmentalist (fiscal and welfare) policies sometimes termed "liberal" neodevelopmentalism. ${ }^{4}$ The discussion over how to correctly characterize the policy regime in place is a legitimate one but is hard to settle. Yet, the crucial point is to uncover the underlying politico-economic forces behind the configuration of the policy regime associated with Brazil's recent experience.

Most accounts of Brazilian neodevelopmentalism simplistically consider the state-or, more concretely, policy makers-as the active subject of the historical process and, hence, as the fundamental force behind the emergence of this policy regime. Others, instead, point at deeper-level class relations as the main determinants of state actions and policy configurations. Both theoretical approaches, however, fail to realize that, as a social relationship, the capitalist state is one of the instances, albeit the most general one, through which individuals, as collective personifications of commodities, relate to one another in the organization of the process of social reproduction. This article will advance an explanation of the emergence and consolidation of so-called new developmentalism or "liberal" neodevelopmentalism in Brazil that draws on the theoretical insights on global/national and state/market dynamics advanced by the Marxian critique of political economy, namely, that the process of capital accumulation is global in terms of its general dynamics and historical potencies and national only in its

2. See, e.g., R. Roett, "How Reform Has Powered Brazil's Rise," Current History 109 (201): 47-52; S. Edwards, Left Behind: Latin America and the False Promise of Populism (Chicago: University of Chicago Press, 2010).

3. See, e.g., N. Barbosa and J. A. P Souza, "A inflexão do Governo Lula: Política econômica, crescimento e distribuição de renda," in Brasil: Entre o passado e o futuro, ed. E. Sader and M. A. Garcia (São Paulo: Fundação Perseu Abramo e Editora Boitempo, 2010), 57-110; A. Moreira Amado and M. Rollemberg Rollo, "The 'Developmentalism' Debate in Brazil: Some Economic and Political Issues," Review of Keynesian Economics 3 (2015): 77-89.

4. See, e.g., A. Saad-Filho and L. Morais, "Neo-Developmentalism and the Challenges of Economic Policy-Making under Dilma Rousseff," Critical Sociology 38 (2012): 789-98; C. Ban, "Brazil's Liberal Neo-Developmentalism: New Paradigm or Edited Orthodoxy?," Review of International Political Economy 20 (2013): 298-331. 
forms of realization. It also claims that political processes are modes of existence of economic relations. ${ }^{5}$ These insights will yield an explanation of Brazil's recent experiences that relates them to the specific characteristics of the local process of capital accumulation and that uncovers the period's structural connection with previous politico-economic configurations, thus overcoming the one-sidedness of mainstream, nation- and politics-centered accounts.

It will be argued here that the process of capital accumulation in Brazil has revolved, since its origins, around the appropriation of the local ground rent by different social subjects, in particular its recovery by industrial capital, as has been the case in most other national spaces of accumulation that participate in the international division of labor as primary commodity producers. ${ }^{6}$ This specific modality of capital accumulation, it will be claimed, has come about through specific state policies and politico-economic processes. Liberal neodevelopmentalism, then, will be regarded as the political form of realization of the Brazilian process of capital accumulation in a period when the ground rent available for appropriation experienced a substantial expansion, crucially vis-à-vis the previous two decades, yet remained insufficient to sustain a major process of industrial deepening comparable to the one that occurred during the age of "statist" developmentalism. These arguments will be advanced through a reexamination of well-known historical processes that is supported here by a new body of quantitative evidence. The methodology used in this quantitative analysis is briefly outlined in the footnotes and the appendix of this article and extensively discussed elsewhere. ${ }^{7}$

The analysis of the main economic and political manifestations of the Brazilian process of capital accumulation since the period of statist developmen-

5. See K. Marx, Capital, Volume I (London: Penguin, 1976); J. Iñigo Carrera, El capital: Razón histórica, sujeto revolucionario y conciencia (Buenos Aires: Ediciones Cooperativas, 2008); N. Grinberg and G. Starosta, "From Global Capital Accumulation to Varieties of Centre-Leftism in South America: The Cases of Brazil and Argentina," in Crisis and Contradiction: Marxist Perspectives on Latin America in the Global Economy, ed. J. Webber and S. Spronk (Leiden: Brill Academic, 2014), 238-41.

6. Iñigo Carrera, El capital, 150-62. Ground rent is surplus value appropriated by landowners due to their differential and absolute monopoly over uncontrollable natural conditions of production that, respectively, increase labor productivity or allow production altogether. See K. Marx, Capital, Volume III (Harmondsworth: Penguin, 1981), 779-823.

7. J. Iñigo Carrera, La formación económica de la sociedad argentina, vol. 1, Renta agraria, ganancia industrial y deuda externa 1882-2004 (Buenos Aires: Imago Mundi, 2007), 23-39; N. Grinberg, “Transformations in the Korean and Brazilian Processes of Capitalist Development between the Mid-1950s and the Mid-2000s: The Political Economy of Late Industrialisation" (PhD thesis, London School of Economics and Political Science, 2011), 63-103, "Capital Accumulation and Ground-Rent in Brazil: 19532008," International Review of Applied Economics 27 (2013): 449-71, and "On the Brazilian Ground-Rent Appropriated by Landowners: 1955-2005," Brazilian Journal of Political Economy 35 (2015): 799-824. 
talism will reveal the specific characteristics of this process and the historical continuity of its different forms of realization. Moreover, both the analysis of the general dynamics of the process of capital accumulation on a global scale and of its concrete manifestations in Brazil will also shed light on the nature of politico-economic relations between the so-called developing countries and the world capitalist system.

The article is organized as follows. Section I advances an analysis of the general dynamics of the process of capital accumulation that serves as the starting point for the study of the Brazilian experience, crucially of two related sets of relationships: that between national and global developments and that between economic and political processes. Section II presents an analysis of the specific structural characteristics of the Brazilian process of capitalist development and of its main economic and political forms of realization between the mid-1940s and the present, revealing the specificity of the different forms of developmentalism. Section III concludes the article.

\section{ON THE RELATIONSHIP BETWEEN THE ECONOMIC AND POLITICAL FORMS OF REALIZATION OF THE CAPITALIST PROCESS OF SOCIAL REPRODUCTION}

One of Marx's key scientific discoveries was that the historical specificity of the capitalist mode of producing human life resides in that the organization of social labor-that is, the allocation of each of the individual fragments that constitute society's total capacity to produce use values-is regulated autonomously, through the exchange of the products of privately performed individual processes under the form of capitals pursuing no purpose other than maximizing their valorization and expansion; their never-ending accumulation. In other words, the thing-like general social relationship among private and independent producers (commodities/money) develops into the automatic subject of social reproduction (capital), and this process takes the historically specific form, and becomes a byproduct, of the accumulation of the total social capital. Indeed, capital is not simply an instrument of production or a legal/productive unit developed to reduce "transaction costs," as neoclassical economics claims in its different versions, but the material product of privately performed social labor acting as an autonomous power that organizes the allocation of each individual productive fragment and associated consumption process. When social labor is organized under this indirect form, individuals not only have to put all their senses, consciousness, and will into production for markets. They also need to represent in the market the exchangeability of the commodities they own. Hence, in the process of social 
reproduction they relate to each other not as individual persons but as persons whose will resides in the commodities they own and who recognize each other as owners of private property. ${ }^{8}$

Organized as a process of capital accumulation, social reproduction becomes, for the first time in human history, a universal, worldwide process. Not only does the impersonal character of market transactions allow the interaction of geographically dispersed individual fragments of social labor (i.e., productive units in the form of individual capitals), but the boundlessly expansive nature of the process of capital accumulation itself necessarily results in such everincreasing integration. Yet, due to the private form of realization of social labor, capital accumulation started and has so far existed as formally independent, though fully interdependent, national processes that constitute politico-economic units in themselves. The world market, then, is not the context in which individual capitals and national economies develop or simply the sum total of national markets interconnected through flows of commodities, money as capital, and labor power, as mainstream economics considers it. It is the other way around: national markets/economies are integral parts of the totality constituted by the world market/economy, and hence forms of realization of the process of capital accumulation on a global scale. International movements of commodities and "factors of production" are forms through which the global unity of capital accumulation comes about. ${ }^{9}$

Intraclass cooperative relations and interclass antagonistic interactions are political (i.e., direct as opposed to market mediated) forms of organizing the allocation the individual fragments of social labor. Yet, as the outcome of the actions of "free" individuals who are themselves personifications of commodities, those political processes are but forms of realization of the general social relationship of capital accumulation. Put differently, class relations are the form through which individual sellers and buyers of labor power-the commodity whose consumption by capital results in the creation of wealth, value, and surplus value-engage in the collective trading of that commodity in order to maximize/minimize its market price, thus subsuming their inherently competi-

8. Marx, Capital, Volume I, 178-269; M. Postone, Time, Labor, and Social Domination: A Reinterpretation of Marx's Critical Theory (Cambridge: Cambridge University Press, 1996), 75-83; J. Iñigo Carrera, "The Historical Determination of the Capitalist Mode of Production and of the Working Class as the Revolutionary Subject," Critique: Journal of Socialist Theory 42 (2014): 557-59.

9. Marx, Capital, Volume I, 222, 247, 707, 929; Postone, Time, 100, 149, 259; Iñigo Carrera, El Capital, 148-49; P. Burnham, "Open Marxism and Vulgar International Political Economy," Review of International Political Economy 1 (1994): 221-31. 
tive relationship as sellers/buyers of the same commodity into a cooperative one that clashes with that of those at the other pole of the market relation. ${ }^{10}$

The historical specificity of the capitalist state thus develops in this process as the direct representative of the process of capital accumulation in its unity, assuring the normal consumption of labor power and its reproduction with the attributes needed by capital in general to produce surplus value. And, by virtue of such nature, the state subsumes all the direct actions necessary for the normal development of the process of capital accumulation beyond those related to the reproduction of labor power-for example, the centralization of capital in specific sectors through public ownership, market protection, credit policies, state subsidies and legal regulations; the general representation of national processes of capital accumulation in the global political economy. These actions, however, do not develop as a planned, consciously regulated process. Rather, as any other necessary form of realization of the autonomously regulated process of capital accumulation, they develop through profitability crises and class-based political conflicts. ${ }^{11}$

In sum, the actions and antagonistic interaction of social classes, as well as the nation-state policies in which they manifest themselves, should not be seen

10. Marx, Capital, Volume I, 373-413; Iñigo Carrera, El Capital, 95-105.

11. Marx, Capital, Volume I, 779-80; Iñigo Carrera, El Capital, 106-8. This analysis of the capitalist state shares with other Marxist analyses the view that the state is a nonneutral institution, as in mainstream contractualist theories, that yet appears as autonomous of particular interests. However, the analysis of the state pursued here departs from these Marxist approaches in various ways. Crucially, this Marxist tradition, which goes from structuralism-functionalism (N. Poulantzas, "The Problem of the Capitalist State," New Left Review 58 [1969]: 67-83) to Open Marxism (Burnham, "Open Marxism," 221-31), through the German "state derivation" school (J. Hirsch, "The State Apparatus and Social Reproduction: Elements of a Theory of the Bourgeois State," in State and Capital: A Marxist Debate, ed. J. Holloway and S. Picciotto [London: Arnold, 1978], 57-107), does not understand the state as a concrete form of realization of the most general direct social relationship among commodity ownersthe class struggle-through which their general indirect social relationship-capital accumulationcomes about. Rather, those Marxist analyses, explicitly or not, regard the state as an institution whose necessity springs independently of the process of capital accumulation, yet is formally subsumed by capital to fulfill several "functions" that help reproduce the "system" as a whole while gaining some de facto autonomy. Hence, the capitalist state is not understood there as a necessary form of realization of the normal reproduction of capital accumulation, and of its historical potencies, but as a secondbest, contingent solution for capital to address the crisis tendencies and contradictions inherent in the process of accumulation-e.g., intercapital competition, fall in the rate of profit, the power of labor. Even Open Marxism authors who regard the state as a mode of existence of fetishized social relations fail to see the inherently antagonist capitalist class relations that take form in the state as modes of existence of the general social relationship of capital accumulation. Often mixing capital with its personifications, the members of the capitalist class, they fail to recognize the thing-like general social relationship among commodity owners as the alienated subject of social reproduction and social classes as collective personifications of the commodities in which the capital relation is embodied. 
as autonomous forces that determine national developmental experiences, as is the case for the authors commented upon in the introduction. Rather, they should be understood as forms of realization-politicized mediations-of the global process of capital accumulation, through the specific determination of each national portion of the total social capital, which includes the political representation in the world market, with its specifically determined strength, of each national capital vis-à-vis other national portions of global capital. ${ }^{12}$

\section{THE HISTORICAL DEVELOPMENT OF THE BRAZILIAN PROCESS OF CAPITALIST DEVELOPMENT}

As is true of every form of realization of the process of capital accumulation, its global unity is only fully developed in the process of production of relative surplus value. Effectively, beyond the expansion of markets, which requires buyers to have sold something first, capital's global expansion comes about in the process of searching for places where particular natural or historical conditions allow it to reduce the cost of the commodities that directly or indirectly reproduce the labor force, and thus increase the amount of surplus value produced in a given period of time, without investing in technological development. As is broadly acknowledged, this process originally centered on the search for regions where, due to particular natural conditions, raw materials could be produced at a lower cost and gave place to the "classical" international division of labor. ${ }^{13}$

This form of integration of portions of the planet into the global circuits of capital accumulation, however, became embedded with a structural contradiction that determined the long-term pattern of capitalist development. If, on the one hand, the total capital of world society managed to enhance its valorization capacity by reducing the value of labor power, on the other, this was partly offset by the drain of surplus value flowing to the pockets of local landowners in form of ground rent. Global capital became, then, driven to overcome this barrier to its accumulation capacity by establishing an antagonistic association with local landowners in order to recover a portion of that surplus value. Landowners, as social parasites, have had no option other than to accept, not without resistance, losing a portion of the ground rent to industrial capital. From being simply a source of cheap primary commodities, these spaces of accumulation,

12. Iñigo Carrera, El Capital, 150-64.

13. Marx Capital, Volume I, 579-81; G. Howe, "Dependency Theory, Imperialism, and the Production of Surplus Value on a World Scale," Latin American Perspectives 8 (1981): 82-102; Iñigo Carrera, El Capital, 150-51. 
which have included Brazil as a paradigmatic case, became also sources of ground rent for industrial (i.e., productive) capital and its junior partners. ${ }^{14}$

In Brazil, as elsewhere, the accumulation of capital through ground rent recovery has taken a variety of economic and political forms; all involving the mediation of the national state channeling ground rent out of landowners' pockets and creating the conditions necessary to allow its appropriation by industrial capital. This, it should be stressed, does not mean that the state has purposefully acted there as a vehicle for the recovery of ground rent by industrial capital. Rather, crucially since independence, it has unintentionally done so while pursuing, as the political representative of the local process of capital accumulation, the general goal of promoting the development and "modernization" of an economy that, due to its specific participation in the production of relative surplus value on a global scale, has had access to a relatively large ground rent.

From the colonial period until approximately the 1930s, the alliance between capital and landowners over the appropriation of Brazilian ground rent revolved around the production, transport and international trade of various primary commodities. Then, (largely foreign) capitals invested in these and related sectors, as well as the state's foreign creditors, became the landowners' main partners in the appropriation of the local ground rent. Incipiently since the 1920s, and crucially the end of the Second World War (WWII), this position was taken over by capital invested in manufacturing (hereafter, industrial capital), in whose cycle of valorization originated the bulk of the surplus value that formed the ground rent.

The process of so-called import-substituting industrialization (ISI) has been the paradigmatic politico-economic form through which capital accumulation by means of ground rent recovery has come about in Brazil, as in most other primary commodity-producing countries. ${ }^{15}$ This process was consolidated between the 1930s and 1950s, reached its peak during the commodities boom of the 1970s and has been reproduced under increasingly limited and contradictory forms thereafter. In general terms, two indissolubly united types of policy-created mechanisms have shaped Brazilian ISI. Some state policies have indirectly intervened in the turnover cycle of primary sector capital and separated from it a portion of surplus value that could not be other than ground rent, thus interrupt-

14. Iñigo Carrera, El Capital, 151-62. See Iñigo Carrera, "Argentina: The Reproduction of Capital Accumulation through Political Crisis," Historical Materialism 14, no. 1 (2006): 185-219, on the discovery in the Argentinian experience of this specific modality of capital accumulation. See also Grinberg and Starosta, "From Global Capital Accumulation," 241-42.

15. Iñigo Carrera, El Capital, 150-56. 
ing its flow toward landowners' pockets. These have included exchange rate overvaluation, taxes on primary commodity exports and state controls over their domestic and international trade (fig. Al in the appendix shows the evolution of exchange rate over- or undervaluation, and fig. A2 shows the ground rent appropriated by landowners and other social subjects). All of these policies have transferred a portion of ground rent to industrial capitals, by setting domestic prices of raw materials and labor power below international levels and, in the case of exchange rate overvaluation, by reducing the local price of foreign exchange for specific imports and profits repatriation. ${ }^{16}$ These policies have, on a first instance, also transferred a portion of ground rent to the state, not only directly (through the monopoly/control of foreign exchange markets and commodity trade or the taxation of raw material exports) but also indirectly (through the payment of relatively high import taxes and other import-related duties with an overvalued currency). Simultaneously, other policies have allowed the appropriation of the separated portion of ground rent by private industrial capital either through "market mechanisms" or direct state actions. These have included the protection of domestic markets (however varying in degree across periods), the provision of services, industrial inputs and credit at subsidized rates by state-owned companies and banks, the regulated expansion of domestic markets through their activities (i.e., the purchase of locally produced goods and services at inflated prices and an oversized workforce), and direct subsidies.

Effectively, ISI policies and the democratic-populist regimes originally associated with them, both the nationalist and developmentalist variants, did not constitute a "model of development" implemented to solve an "external restriction" (i.e., the alleged decline in the terms of trade of exports and the scarcity of external credit), to employ rural masses migrating to urban centers, nor was it a response to the emerging political power of urban interests, as one-sidedly argued in mainstream accounts. ${ }^{17}$ All these processes were forms of realization of

16. Exchange rate overvaluation and export taxes could be in place only because exported commodities contained ground rent. Otherwise, these policies would have fallen on a portion of capital's normal profits, affecting the normal valorization and reproduction of capital invested in exporting activities. Hence, the effect of those policies passed from commercial to productive (agrarian/mining) capital and from this to landowners.

17. See, respectively, M. Tavares, Da substituição de importações ao capitalismo financeiro: Ensaios sobre economia brasileira (Rio de Janeiro: Zahar Editores, 1977); F. H. Cardoso and E. Faletto, Dependency and Development in Latin America (Berkeley: University of California Press, 1979); R. Kaufman and B. Stallings, "The Political Economy of Latin American Populism," in The Macroeconomics of Populism in Latin America, ed. R. Dornbusch and S. Edwards, National Bureau of Economic Research Conference Report (Chicago: University of Chicago Press, 1991), 15-43. 
the accumulation of capital through ISI rather than its content or historical necessity. Indeed, Brazilian ISI started incipiently in the late nineteenth century, well before these processes even manifested themselves. ${ }^{18}$ Nor would policies and institutions introduced by the military after they took power in the mid1960s constitute any structural break with the previously prevailing model of accumulation, despite arguments to this effect made by scholars from all intellectual traditions. ${ }^{19}$ Nor would the neoliberal policy regime, increasingly introduced by post-1985 democratic governments, constitute a departure from the ISI-based model of development or accumulation, as has been claimed by authors as irreconcilable as Abreu and Saad-Filho. ${ }^{20}$ Rather, all these political developments, as well as the processes of class struggle through which they have come about, have mediated the reproduction, not without transformations, of a structurally unchanged process of capital accumulation based on the appropriation/recovery by industrial capital of a portion of the available ground rent. As noted above, state forms are not the driving force of the accumulation process but one of its mediating instances.

This specific modality of accumulation has allowed industrial capital, crucially foreign owned, to recover a portion of the Brazilian ground rent. Yet, it has rested on inherently contradictory foundations. In order to accomplish the appropriation of ground rent, industrial capital has had to open and close its valorization cycle in the Brazilian domestic market. Otherwise, competition to sell (buy) there above (below) world market prices would have left the rent in landowners' pockets. The domestic market has thus expanded and remained protected to a degree conditioned by the amount of ground rent available to sustain local industrial production. Unable to produce for world markets, where it would have to compete with those industrial capitals that had engendered the Brazilian process of accumu-

18. A. Fishlow, "Origins and Consequences of Import Substitution in Brazil," in International Economics and Development, ed. L. Di Marco (New York: Academic Press, 1971), 311-62.

19. See, e.g., C. Furtado, "The Post-1964 Brazilian 'Model of Development,'" Studies in Comparative International Development 8 (1973): 115-28; M. Simonsen and R. Campos, A nova economia brasileira (Rio de Janeiro: Livaria Jose Olimpo, 1974); C. Anglade, "The State and Capital Accumulation in Contemporary Brazil," in The State and Capital Accumulation in Latin America, vol. 1, ed. Christian Anglade and Carlos Fortin (London: Macmillan, 1985), 52-138; Fernando Veloso et al., "Determinantes do "milagre" econômico brasileiro (1968-1973): Uma análise empírica," Revista Brasileira de Economia 62 (2008): 22146.

20. See M. de Paiva Abreu, "The Brazilian Economy, 1980-1994," in The Cambridge History of Latin America, vol. 9, Brazil since 1930, ed. L. Bethel (Cambridge: Cambridge University Press, 2008), 320-33; A. Saad-Filho, "Neoliberalism, Democracy, and Development Policy in Brazil," Development and Society 39 (2010): 1-28. 
lation, the scale of local industrial production has been, since its origins, limited to the size of domestic markets, which has restricted the use and development of the most advanced technology. Hence, although foreign-owned industrial capital has, on the one hand, managed to valorize normally in Brazil while recycling obsolete equipment and avoiding competition in world markets with parent houses, on the other, its accumulation capacity has depended, as has that of locally owned capital, on the evolution of the size of the ground rent available for appropriation. This is true because reproduction of industrial capital on an expanded scale has required, ceteris paribus, a growing amount of ground rent. Appropriation of ground rent has also been necessary to compensate for the ever-growing difference between local and world market production costs. This difference results from the gap between local and world market scales of production, which generates different technological profiles and, thus, different levels of labor productivity (see fig. A3 for the evolution of labor productivity in Brazil relative to US levels). ${ }^{21}$ Moreover, by lowering domestic primary commodity prices, indirect policy-mediated appropriation of ground rent by social subjects other than landowners has restricted the intensive and extensive application of capital in the primary sector, and thus the growth of labor productivity and of ground rent. In other words, these policies have pushed out of production portions of capital that, had they not been in place, would have yielded normal profits and some rent. ${ }^{22}$

The rest of section three analyzes the most critical nodes in the unfolding of this contradictory developmental pattern between the end of WWII and the present, uncovering the historical necessity and structural continuity behind the seemingly diverse political and ideological forms of realization of the process of capital accumulation, especially the different forms of developmentalism.

A. FROM THE POPULIST TO THE TRIPLE ALLIANCE:

THE CONSOLIDATION OF STATIST ISI

As had been the case since at least the final years of the nineteenth century, between the end of WWII and the mid-1950s, the Brazilian process of capital accumulation through ground rent recovery manifested itself in the proliferation of small, nationally owned industrial capitals. Yet in contrast to pre-WWII experiences, it also came about through the creation of a large number of state-

21. P. Salama, "Specificités de l'internationalisation du capital en Amérique latine," Revue Tiers Monde 19 (1978): 259-97.

22. Iñigo Carrera, La formación económica de la sociedad argentina, 1:101-22. 
owned enterprises (SOEs) in basic industries and public services as well as developmental banks, in some cases through the nationalization at inflated prices of foreign interests. Combined with market protection for local "infant" industry and exchange rate overvaluation, channeling resources from "traditional" agrarian activities benefiting from large increases in world market prices to the emerging manufacturing sector, those forms of direct regulation of social labor shaped the statist ISI process through which the appropriation of ground rent by others than landowners would came about (see fig. A4 for the evolution of GDP and industrial value added). ${ }^{23}$

Both types of capitals—small, privately owned and state owned-would subsequently support the valorization processes of foreign capital subsidiaries. Yet their emergence came about through the consolidation of a nationalisticpopulist state, especially during the commodities boom associated with the Korean War, ${ }^{24}$ when the ground rent available to support the process of capital accumulation grew strongly (see fig. A2). The state-mediated expansion of these capitals needed to take political and ideological form as the first steps in the genesis of a process of economic development allegedly based on national autonomy, self-determination, and, therefore, self-sufficiency. ${ }^{25}$ Moreover, statemediated increases in wages and welfare provisions were also required to generate the industrial workforce through rural/urban migration, to upgrade industrial workers' skills and to make effective the enlargement of domestic markets for the expanding output of consumer goods (see fig. A3 in the appendix for the evolution of real industrial wages). ${ }^{26}$

The specific characteristics and dynamics of the Brazilian process of capital accumulation manifested themselves in specific class relations mediating the development of such state policies and political institutions. The consolidation of the state-led process of ISI, through which the recovery of ground rent by industrial capital came about, thus took shape in the reconfiguration of the process of class struggle. Produced and reproduced in the Brazilian process of capital

23. W. Baer, Industrialization and Economic Development in Brazil (Homewood, IL: Irwin, 1965), 61-77; A. Kohli, State-Directed Development: Political Power and Industrialization in the Global Periphery (Cambridge: Cambridge University Press, 2004), 137-91; Abreu, "Brazilian Economy."

24. For the analysis of post-WWII "commodity booms," see M. Radetzki, "The Anatomy of Three Commodity Booms," Resources Policy 31 (2006): 56-64.

25. On the ideological positions associated with the populist-nationalistic state, see T. Skidmore, Politics in Brazil, 1930-1964: An Experiment in Democracy (Oxford: Oxford University Press, 2007), 88-90.

26. Cardoso and Faletto, Dependency and Development, 127-43; J. Wells, "Industrial Accumulation and Living Standards in the Long-Run: The São Paulo Industrial Working Class, 1930-75, Part II," Journal of Development Studies 19 (1983): 323-26. 
accumulation, the local working class developed with an intrinsic limit to its historical potencies. From its origins, it showed considerable traits of dualism, as the existing surplus population allowed capital to underpay the portion of the country's workforce engaged in nonindustrial activities. Moreover, with a restriction on the growth of the scale of production set by the specifically limited size of the domestic markets, the Brazilian working class has never aimed at controlling the state and, through this, the process of industrial production beyond basic industries, as was the case in Europe during the post-WWII period. Hence, the anarchist and socialist trade union movement that had predominated in the first decades of the twentieth century was disarticulated and replaced, through state actions, with trade unions that focused on economic disputes and rapidly became quasi-state organizations providing services for their members. The bourgeoisie, now largely composed of personifications of small national capitals, had its fate tied to the appropriation, through state policies, of a portion of the local ground rent, which, as noted, grew in size during this period. These two social classes were the main pillars of the statist, nationalistic ISI process. On the other side of the politico-economic spectrum, landowners and representatives of foreign capital saw their place in the business of ground rent appropriation sidelined during this period. The former lost a large mass of the growing ground rent to industrial capital, while the latter momentarily retreated from center stage of the process of industrial development. The reproduction of the Brazilian process of capital accumulation during this formative stage thus took a paradigmatic political form: the so-called populist alliance between the national bourgeoisie and the urban working class, represented by the Social-Democratic Party (PSD) and the Brazilian Labour Party (PTB), respectively, against landowning and foreign capital interest, represented by the National Democratic Union. This form of class dynamics reached its climax during Vargas's 1950-54 government. ${ }^{27}$

Through the mid-1950s, however, some of the features of Brazilian capitalist development started to change when large flows of foreign-owned industrial capital, then pursuing a new phase of global expansion, began to arriveattracted by the substantial growth of the highly protected domestic markets made possible by the enlarged ground rent. ${ }^{28}$ However, the extended inflow of foreign capital to the most dynamic branches of Brazilian industry-now deemed necessary by policy makers and capital's ideologues at home and abroad

27. Skidmore, Politics in Brazil, 54-64; L. Bethell, "Politics in Brazil under the Liberal Republic, 1945-1964," in Bethell, Cambridge History of Latin America, 9:88, 93-96.

28. Cardoso and Faletto, Dependency and Development, 157-58. 
to solve a weakening balance of payments position and to accelerate technological upgrading-could not be mediated politically by the nationalistic government that had created the conditions for this to occur. In the context of a short-lived political and economic crisis, the so-called populist alliance thus became developmentalist. The nationalist and corporatist factions related to the PTB went into a secondary position, while the more business-friendly PSD-associated sectors took the leadership. ${ }^{29}$ To entice multinational corporations (MNCs) into the Brazilian economy, special tax concessions were added to those state policies already promoting local manufacturing as a form of channeling ground rent to industrial capital (largely the combination of exchange rate overvaluation for exports and capital goods imports, market protection, and public sector activities). The Targets Plan (1956-60), launched during Kubitschek's government to improve state provision of infrastructure and basic inputs and to develop the consumer durable and capital goods industries, provided the institutional framework for this policy shift. $^{30}$

As noted above, the extensive establishment of MNC subsidiaries producing consumer durables and, later on, capital goods did not change the structure and dynamics of the Brazilian process of capital accumulation. In sharp contrast to the strategies followed in their countries of origin or other regions where they were then operating (e.g., Canada, Western Europe and, later, the United States), MNCs did not set up productive facilities in Brazil with the technical conditions needed for competition in world markets. Rather, as had been true in the $1910 \mathrm{~s}$ and 1920s, they entered the Brazilian economy with technical scales of production limited to the magnitude of the internationally small domestic market where, like local capitals, they sold their entire output. They managed to do so because they were able to compensate for the extraordinary costs arising from their suboptimal scale of production by complementing normal surpluses with a portion of the available ground rent and of the profits of the smaller, nationally owned, capitals with which they entered in contact in the marketplace. In other words, MNCs arrived in Brazil to recover a portion of the local ground rent by producing on a small scale for the domestic market. The country's participation in the international division of labor, and thus in the production of surplus value on a global scale, remained unchanged: exporting rent-bearing raw materials and importing industrial goods, increasingly in the form of inputs and equipment.

29. C. Anglade, "The State and Capital Accumulation," 56-57; Skidmore, Politics in Brazil, 146-49.

30. A. J. Avelãs Nunes, Industrialización y desarrollo: La economía politica del modelo brasileño de desarrollo (Mexico City: F.C.E., 1990), 188-93; Kohli, State-Directed Development, 183-84. 
Despite the robust growth and rapid industrial development occurring in the period up to the second part of the 1950s, the limited and contradictory dynamics of the Brazilian process of capital accumulation generated crisis. Already in the late 1950s, economic growth slowed markedly and inflation and balance of payments problems reappeared as the ground rent available for appropriation contracted, while primary commodity prices collapsed in the aftermath of the Korean War (see fig. A2). The developmental-populist state, the political representative of the Brazilian process of capital accumulation, avoided crisis by finding a new source of extraordinary (compensatory) surplus value, namely, loanable capital inflows, increasingly in the form of credit from private international suppliers of equipment used in state infrastructural and heavy-industry projects (see fig. A5 for the evolution of net loanable capital inflows and ground rent appropriated by others than landowners relative to total surplus value). Foreign credits, however, soon proved to be insufficient and unreliable. ${ }^{31}$ The stagnant ground rent, then largely appropriated by others than landowners through different taxes and regulations on primary commodity exports, ${ }^{32}$ would began to be complemented by a third source of extraordinary surplus value: that arising from the squeezing of manual workers' wages (see fig. A3). ${ }^{33}$ This new transformation in the forms of realization of the Brazilian process of capitalist development did not come about smoothly. Rather, it was realized through a profound politico-economic crisis that expressed the clash of the process of capital accumulation against its intrinsic quantitative limit given by the amount of ground rent available for appropriation. ${ }^{34}$

Although necessary for the normal valorization of industrial capital under its specifically limited modality of accumulation, the payment of labor power below its value could hardly have been accepted by the Brazilian working class. In 1964, after two years of economic crisis, the military removed Goulart's populist

31. Avelãs Nunes, Industrialización, 210-11; J. Frieden, "The Brazilian Borrowing Experience: From Miracle to Debacle and Back," Latin American Research Review 22 (1987): 95-131.

32. Various forces explain the replacement of exchange rate overvaluation with export taxes as the general form of ground rent appropriation by social subjects other than landowners. First, in the context of falling prices and productive diversification, locally set commodity-specific export taxes became more "efficient" mediations than multiple exchange rates. Second, backed by landowners, the post-1964 military government had the political power to implement such "visible" forms of ground rent taxation and to administer the resources thus raised. Third, as the period of private-sector, heavy fixed-capital investments and, hence, large equipment imports had ended, exchange rate overvaluation lost part of its necessity for accumulation process.

33. D. Zurron Ocio, "Salarios e politica salarial," Revista de Economia Politica 6 (1986): 8-11

34. Skidmore, Politics in Brazil, 187-302; Abreu, "Brazilian Economy," 349-59. 
unions-backed government through a coup actively supported by large segments of the local bourgeoisie (especially those producing nonwage goods), landowners, and most of the direct political representatives of foreign-owned industrial capitals (crucially, the US government). ${ }^{35}$ US-trained "technocrats" then took charge of economic policy making, while an authoritarian regime suppressed any political opposition to real-wage reductions. Initially, an eclectic combination of heterodox and orthodox policies was implemented. To control for the ensuing inflationary crisis, the budget was rebalanced through current-expenditure cuts and tax increases, while the supply of credit was restricted and labor-market "flexibility" enhanced. Inflation was also targeted through mainstream supply-side policies: capital-market deepening was promoted through de-regulation, indexation and a state-managed forced-savings system. These state policies and institutional reforms mediated politically the contraction of the sources of extraordinary social wealth (ground rent and loanable capital inflows complementing it) that had been supporting the process of capital accumulation, without which the economy stagnated, and the emergence of the new source of extraordinary surplus value for industrial capital, coming from the payment of semiskilled labor power below its value or full costs of reproduction. Finally, to try revive capital inflows, existing restrictions to private-sector external borrowing and foreign capital profit remittances were lifted. ${ }^{36}$

Eventually, as Eurodollar capital markets boomed, in 1968 loanable capital flows to Brazil became positive again (see fig. A5). Under the then-fashionable structuralist argument that the stubborn inflationary process was caused by supply bottlenecks, state policies recovered most of their developmentalist, and some of their demand-side expansionist, features. This change in the orientation of economic policy found institutional expression in a series of industry plans that culminated in the first National Development Plan (NDP) for 1972-74. ${ }^{37}$ As

35. The PTB's Goulart had been Kubitshek's deputy during the period 1956-60 and was reelected for 1961-65 as the deputy for UDN's last-minute candidate, Quadros. Then, president and deputy were chosen separately and could be members of different parties. Goulart assumed the presidency in 1961 after Quadros unexpectedly resigned when he lost the support of his "adoptive" party. See Skidmore, Politics in Brazil, 187-204; Bethell, "Politics in Brazil," 129-37.

36. Avelãs Nun es, Industrialización, 316-30; Skidmore, Politics in Brazil, 187-92; A. Lara Resende, "Estabilizacao e reforma: 1964-1967," in A ordem do progresso: Cem anos de politica economica republicana (1889-1989), ed. M. de Paiva Abreu et al. (Rio de Janeiro: Campus, 1990), 213-31.

37. A. Fishlow, "Origins," 97-99; L. A. Correa de Lago, "A retomada do crescimento e as distorções do 'milagre': 1967-1973," in Abreu et al., A ordem do progresso, 236-37; Avelãs Nunes, Industrialización, 377-92; Abreu, "Brazilian Economy," 370-74. 
figure A4 indicates, economic growth finally picked up. This time, however, the economic expansion was combined with harsh political repression, reinforced state control of working-class organizations, and further strengthening of MNC participation in the industrial sector, especially as large portions of small nationally owned capital had collapsed during the 1963-66 recession. These elements solidified the so-called Triple Alliance between domestic, foreign, and state capital, which replaced previous populist arrangements; developmentalism became authoritarian. ${ }^{38}$ It is, then, apparent that populism, both under the nationalist and developmentalist variants, had been but a moment (a political mediation) in the structuring of a process of capital accumulation based on the recovery of ground rent by global industrial capital.

Hence, despite the many changes in economic policies and political institutions occurring during this period, the previous pattern of capital accumulation was not superseded in favor of an outward-oriented and market-friendly finetuning of the developmentalist project, as has been argued by neoliberal authors of both old and new vintage. ${ }^{39}$ Rather, the specifically limited modality of capital accumulation was regenerated. The particularity of the period arose from the fact that the ground rent was complemented, in supporting industrial capital's normal valorization, with large loanable capital inflows and a portion of the value of manual workers' labor power, including a share of the forced savings captured by the state through below-inflation adjustments of accumulated funds. ${ }^{40}$ Effectively, while the ground rent appropriated by capital made up around 14 percent of total surplus value during the so-called economic miracle (1968-73), net loanable capital inflows constituted a further 5 percent (fig. A5). Industrial capital kept selling almost its entire output in an internationally small domestic market that, despite the claims of openness, remained highly protected by tariffs and nontariff restrictions such as the Law of Similarity, which banned imports of goods competing with local production. ${ }^{41}$ In fact, the much-celebrated reduction of import taxes during this period simply reflected (and compensated for) the reduction of the exchange rate to the currency's exchange parity (see fig. Al),

38. P. Evans, Dependent Development: The Alliance of Multinational, State and Local Capital in Brazil (Princeton, NJ: Princeton University Press, 1979); A. Kohli, State-Directed Development, 190-210.

39. See, respectively, Simonsen and Campos, A nova economia; Veloso et al., Determinantes.

40. F. Oliveira et al., "A Rentabilidad do FGTS," texto para discussao no. 637 (IPEA, Rio de Janeiro, 1999).

41. C. Von Doellinger et al., A politica Brasileira de comercio exterior e sus efeitos: 1967-73 (Rio de Janeiro: IPEA, 1974), 134; Anglade, "The State and Capital Accumulation," 74-75; Avelãs Nunes, Industrialización, 408-15; Correa de Lago, "A retomada," 272-78. 
which was resulting in an increase in the cost of imports. Moreover, under the claim that it was a policy implemented to expand local export capacity and overcome the limits to the scale of industrial production imposed by the narrowness of domestic markets, a new form of ground rent appropriation emerged during 1968-73: the promotion, through lavish subsidies, of industrial exports.

B. FROM THE OIL TO THE DEBT CRISIS: THE PEAK AND CRASH OF STATIST ISI

By the end of 1973, the politico-economic forms of realization of the Brazilian process of capital accumulation changed again when the two main sources of extraordinary social wealth available to sustain its reproduction through ISI enjoyed a strong expansion. The first oil shock was then manifesting itself in the sharp rise in international primary commodity prices and in the expansion of the global credit supply. In 1974, the magnitude of the Brazilian ground rent appropriated by others than landowners and loanable capital inflows thus peaked, becoming around 28 percent and 10 percent of all surplus value, respectively (see figs. A2 and A5).

Once more, changes in economic conditions came about through changes in state policies and political institutions. Not only was the payment of labor power below its value no longer necessary for capital's normal valorization. The enlargement of domestic markets for mass-consumed durable goods was now needed to absorb the expanding industrial output. ${ }^{42}$ The hardliners within the military, who had governed through the "miracle," were no longer capable of expressing politically the necessities of the process of capital accumulation. They were replaced by "moderate" colleagues who implemented a policy mix reminiscent of the pre1964, populist era. The exchange rate became, again, overvalued and import taxes were increased to compensate for this, thus expanding the portion of an enlarged ground rent directly appropriated by industrial capital and the state (see fig. Al). Taxes and controls on primary commodity exports remained in place, especially during years of high international prices. Industrial exports promotion, notably of motor vehicles, was enhanced through increases in subsidies that more than com-

42. The Brazilian state, nevertheless, continued using resources from various forced-saving programs to fund public and private investments, hence transferring a portion of them to industrial capital through below-inflation adjustments. 
pensated for the overvaluation of the national currency. Legal regulations on wage adjustments were relaxed, while a process of political distention was promoted and independent trade unions legalized. ${ }^{43}$ Moreover, under the ideological form of a need to address the quadrupling of oil prices, the military government launched the NDP II (1975-79), and various industry-specific initiatives, to deepen the ISI process by increasing the production of industrial inputs and the provision of infrastructure by state firms, especially in hydroelectricity-generating facilities, and the production of capital goods by private nationally owned companies. The plan, it was aimed, would keep economic growth at 10 percent annually and transform Brazil into a global industrial and, thus, political power. Additionally, it would also attempt to correct the prevailing severe regional and income disparities. This, the military government claimed, was not only desirable on moral and political grounds but would also contribute to the expansion of the domestic market for consumer durables. ${ }^{44}$

During the 1970s, the ground rent, and the inflow of loanable capital complementing it, experienced a strong, yet irregular, expansion (see figs. A2, A5). Although not without difficulties, the second NDP proceeded apace. With these enlarged masses of extraordinary social wealth sustaining the process of capital accumulation, the Brazilian economy was not only able to sustain high growth rates (see fig. A4). It also underwent a major industrial deepening. The developmentalist ISI process reached its peak, advancing to include almost all sectors of production. ${ }^{45}$

The quantitative expansion and qualitative development of the industrial sector during the second half of the 1970s manifested itself in sharp increases in employment levels and wages (see fig. A3). For the process of capital accumulation, wage increases became necessary not only to expand the domestic markets for durable-consumer goods, as noted, but also, and crucially, to reproduce a labor-force undertaking increasingly more complex and intensive industrial activities. Yet, capital and its general political representative, the state, did not grant those improvements in payment conditions on their own initiative. On

43. C. Anglade, "The State and Capital Accumulation," 71-75, 92-95; T. Skidmore, The Politics of Military Rule in Brazil, 1964-1985 (Oxford: Oxford University Press, 1988).

44. Government of Brazil, II National Development Plan (1975-1979) (Brasilia: IBGE, 1974); J. Batista, Debt and Adjustment Policies in Brazil (Boulder, CO: Westview, 1992); R. Carneiro, Desenvolvimento em crise (São Paulo: Editora UNESP, 2002), 55-64.

45. L. Correa do Lago et al., A indústria brasileira de bens de capital: Origens, situação recente e perspectivas, Estudos Especiais IBRE 1 (Rio de Janeiro: FGV, 1979), 375-418; Batista, Debt and Adjustment Policies. 
the contrary, this process came about through a strong surge in labor's militancy, permitted by the process of political distention, known as "opening" after 1978. Working-class political advance took form in a series of widely supported strikes by core industrial workers and through the emergence of the so-called new unionism and the Workers Party (PT). ${ }^{46}$

These relatively favorable conditions, however, would not last long. At the turn of the decade, the Brazilian process of capital accumulation began, once more, to come up against its objective quantitative limit. The second oil shock was, unlike the first one, followed by an increase in international interest rates and a sharp fall in the prices of primary commodities other than oil. As the ground rent and loanable capital inflows began a process of sharp contraction, the Brazilian economy entered a period of crisis and instability (see figs. A2, A4, A5). Most of the policies that had transferred these resources to industrial capital, thus supporting its valorization and development, were either reduced in their scope or removed altogether. In late 1979, a new economic package was implemented, sharply devaluing the national currency, dismantling a large part of the tax and regulatory system protecting domestic markets (e.g., the Law of Similarity) and significantly reducing the size of state subsidies granted to industrial capital. The third NDP, which was meant to continue during 1980-86 the transformations started by its predecessors, became more a vague expression of hope about unrealistic growth prospects than an articulated and properly calibrated economic program. ${ }^{47}$ The previous process of political opening came to a halt and trade union activism began to be met, once again, with fierce state repression. Industrial wages thus started a process of contraction that partly compensated for the impact of the reduction of the available ground rent on capital's profits. When, in 1982, the international crisis became apparent in the sharp, further retraction of global demand (and thus of primary commodity prices) and of credit supply to developing countries, the Brazilian economy was already in a profound recession. ${ }^{48}$

46. Skidmore, Politics, 204-6, 212-15; Anglade, "The State and Capital Accumulation," 99-100; R. Antunes and M. A. Santana, "The Dilemmas of the New Unionism in Brazil, Breaks and Continuities," Latin American Perspectives 41 (2014): 10-21.

47. Anglade, "The State and Capital Accumulation," 102-3; Skidmore, Politics of Military Rule in Brazil, 216-17.

48. Anglade, "The State and Capital Accumulation," 103-6; D. Dias Carneiro, "Long-Run Adjustment, Debt Crisis and the Changing Role of Stabilisation Policies in the Recent Brazilian Experience," in Latin American Debt and the Adjustment Crisis, ed. R. Thorp and L. Whitehead (London: Macmillan, 1987), 28-67; Frieden, “Brazilian Borrowing Experience," 116-19. 


\section{THE LOST DECADE: THE CRISIS OF STATIST ISI}

During the second half of the 1970s, the Brazilian process of capital accumulation reproduced itself under enlarging, yet increasingly unstable and unsustainable bases. The contradictions inherent to its specific structural characteristics turned into open crisis during 1979-82, when the ground rent and loanable capital inflows contracted strongly. During most of the 1980s and early 1990s, these shrank to their minimum levels. The clash of the process of capital accumulation against its specific limit became ever more dramatic. As this occurred, the dismantling of the state policies that had realized the appropriation of ground rent by industrial capital accelerated. This was thus a period of recurrent crises. The Brazilian economy came out it significantly transformed, with the size of its industrial sector reduced and its deepening, which had been largely accomplished during the 1970s, drastically reversed. Developmentalism would then give place to neoliberalism as the general political form of realization of the Brazilian process of capital accumulation and the ISI process would become increasingly limited.

During the first half of the 1980s, the reversal of loanable capital flows and the reduction of the size of the ground rent resulted in the implementation of a stabilization program designed with the agreement of the International Monetary Fund (IMF). ${ }^{49}$ The national currency was sharply devalued and public sector expenditures (especially in infrastructure and social welfare) were largely curtailed, thus eliminating various mechanisms of ground rent transfer to industrial capital. The Brazilian economy thus contracted (see fig. A4). Nevertheless, despite the government's orthodox rhetoric, public sector accounts remained in deficit as revenues dropped, and, crucially, the sharp expansion of external debtservicing could not be fully compensated for by expenditure cuts. A portion of this deficit was financed through borrowing in domestic capital markets. The rest was monetized, rapidly fueling the inflation rate. The debt crisis thus manifested itself in a inflationary crisis. ${ }^{50}$

Yet, despite the negative prospects, by mid-1984 the Brazilian economy started to recover, pulled by the strong external demand for intermediate industrial goods, crucially, from the US economy, which was then booming. ${ }^{51}$ As such this export-led recovery, unlike previous ones, was not the product of a sustained

49. Dias Carneiro, "Long-Run Adjustment," 45-47; Frieden, "Brazilian Borrowing Experience," 120.

50. Batista, Debt and Adjustment Policies, 122-24.

51. Frieden, "Brazilian Borrowing Experience," 120-21; Batista, Debt and Adjustment Policies, 136. 
increase in primary commodity prices, and thus in the magnitude of the ground rent, or large loanable capital inflows. Conversely, it occurred in the context of large loanable capital outflows, paid for by with a portion of surplus value produced domestically, and agrarian landowners appropriating the entire rent. Nor did the export-led recovery result from the improved efficiency of Brazilian industry after the structural transformation allegedly undergone throughout the 1970s, or from the compression of the domestic absorption of local output, as suggested elsewhere. ${ }^{52}$ Rather, it resulted from the combination of three other forces that expressed the contradictory reproduction of the Brazilian process of capital accumulation. First, the promotion of exports through a strongly undervalued currency-a by-product of domestic-debt-funded state purchases of foreign exchange for external-debt-servicing-and through the export subsidies that were still in place. ${ }^{53}$ Second, a sharp reduction of industrial wages occurred during 1982-84 (almost 40 percent in real terms), which increased the international competitiveness of local industrial production. The reduction of domestic absorption was an expression of such drastic wage compression. Third, a surge in the rents of hydroelectricity-generating lands available for appropriation by industrial capital through low-priced energy (see fig. A2). This was especially notable in the energy-intensive heavy and chemical industries. Moreover, a portion of the ground rent, and of foreign credits materialized in the second NDP investments, was then being transferred to industrial capital through SOE activities. Despite the administration's orthodox rhetoric, real prices of SOE output fell continuously during the first half of the 1980s under the rather heterodox argument of being a measure to control inflation. In other words, the implicit subsidy consisted of previously invested, and not fully recovered, capital. ${ }^{54}$

With the economy growing and labor-market conditions improving, the relaxation of wage-adjustment regulations was imminent. This new policy shift, however, could not be administered by a military government that was committed to a harsh economic adjustment program and had been losing political support consistently, crucially from hitherto supportive business sectors. In early 1985, the new economic conditions thus manifested themselves in a change in the political forms of realization of the process of capital accumulation: the in-

52. See, respectively, A. Barros de Castro and F. Souza, Economia brasileira em marcha forçada (Rio de Janeiro: Paz e Terra, 1985); Carneiro, Desenvolvimento 165-78.

53. H. Shapiro, "Automobiles: From Import Substitution to Export Promotion in Brazil and Mexico," in Beyond Free Trade Firms, Governments, and Global Competition, ed. D. Yoffie (Boston: Havard Business School Press, 1993), 216-23.

54. Batista, Debt and Adjustment Policies, 144-45; Carneiro, Desenvolvimento, 185-86. 
direct election of a civilian president, former cabinet minister in the 1950s and 1960 s populist governments, and the subsequent reestablishment of democratic institutions. ${ }^{55}$

By early 1986, economic policies began to recover some of their pre-debt-crisis, developmentalist shape when the accumulation of foreign exchange reserves (due to the enlarged trade surpluses and a drop in global interest rates) allowed the implementation of the heterodox Cruzado Plan to stop spiraling inflation without contractive measures. Under the argument that inflation was inertial, prices were frozen in order to change economic agents' "expectations." However, while prices of foreign exchange and SOE output were immediately frozen, wages received first a 33-percent increase. Domestic consumption thus expanded, while industrial costs remained somehow under control. State investments in infrastructure and capital formation increased for the first time in many years. ${ }^{56}$ Strong economic growth continued, while inflation fell substantially. The latter, however, was only due to the unsustainable price freeze. Once the all-important November elections had passed, controls, especially on SOE output prices, were removed and inflation rocketed again; the new government had not stopped monetizing its deficits, which had been further increased during the price-freeze period. Moreover, the economic recovery was also coming to a halt as a consequence of its own limited bases. Sharp real-wage increases occurring during 1985-86, partially fed by the adjustment mechanism included in the Cruzado Plan and allowed by the new political institutions, together with the mild strengthening of the currency, were undermining the international competitiveness of industrial exports, while a severe harvest failure was reducing those of agrarian goods (and the ground rent available for appropriation by different social subjects). Trade surpluses shrank sharply throughout the second part of 1986 and the state could no longer service the public sector's massive debt with external creditors. In February 1987, it unilaterally declared the moratorium on interest payments to commercial banks, further indicating the limits of the Brazilian process of capitalist development. ${ }^{57}$

Several other heterodox attempts were made between the late 1980s and the early 1990s to control inflation and restart growth; all failed. ${ }^{58}$ Ground-rent having

55. Skidmore, Politics of Military Rule, 244-55; Frieden, "Brazilian Borrowing Experience," 120-21.

56. E. Modiano, "A ópera dos três cruzados: 1985-1989," in Abreu et al., A ordem do progresso, 36264; N. Nazmi, "Inflation and Stabilization: Recent Brazilian Experience in Perspective," Journal of Developing Areas 29 (1995): 491-506, esp. 492-93; Carniero, Desenvolvimento, 195.

57. Modiano, "A ópera," 365.

58. Carniero, Desenvolvimento, 193-224. 
already contracted, and with loanable capital outflows in continuous expansion as global financial markets tightened again after the 1987 stock market crash, ${ }^{59}$ the Brazilian process of capital accumulation was deprived of the two main sources of extraordinary social wealth that had been complementing normal surplus value and thus sustaining capital's valorization. Economic policies became increasingly contractive and the dismantling of ISI-supporting measures regained momentum, especially during the short-lived government of maverick, right-wing populist Collor de Mello (1990-92). Under the neoliberal dogma of market efficiency, tariff protection was largely, though not universally, scrapped; several SOEs were privatized; and public sector welfare expenditures, employment, and wages were cut. $^{60}$

Under these conditions, the real value of domestic output contracted by a 3.5 percent annual average, while total manufacturing value added collapsed by one-third during 1987-93. Unemployment mounted and real industrial wages fell by a 9 percent yearly average (see figs. A3, A4). Another source of extraordinary surplus value then arose to complement the ground rent in sustaining the process of capital accumulation, namely, the general payment of labor power below its value. This time, a military coup was not necessary to mediate politically those developments. The increase and consolidation of the industrial reserve army throughout the 1980s had reduced the capacity of the working class to oppose such a process. Moreover, an essentially nationalistic military could have hardly represented politically a process of capital accumulation realized through radical domestic-market opening and the sale at fire-sale prices of stateowned heavy-industry companies.

\section{CONSERVATIVE MODERNIZATION: CONSOLIDATION}

\section{OF NEOLIBERAL ISI}

Between 1993 and 1997, international credit markets experienced a new period of relatively high liquidity, as a form of realizing the process of overproduction of capital on a global scale through the expansion of the credit supply. ${ }^{61}$ As credit-fueled global growth accelerated, demand for raw materials strengthened

59. G. Kaminsky, "International Capital Flows, Financial Stability and Growth," DESA working paper no. 10 (United Nations, New York, 2005), 10.

60. Nazmi, "Inflation and Stabilization," 497-504.

61. R. Brenner, The Economics of Global Turbulence (London: Verso, 2006), 143-63, 267-343; Iñigo Carrera, El Capital, 181-233. 
and so did their prices. With local primary production thus stimulated and productivity increases taking place, the Brazilian ground rent enlarged substantially. Moreover, during this period, unlike in the 1980s, global credit supply expanded sufficiently to reach developing countries. As an expression of these global-market developments, in 1993 Brazil finally reached an agreement with its foreign creditors and fresh loanable capital inflows were reestablished (see figs. A2, A5). The forms through which these complemented the ground rent in supporting capital's valorization, however, would differ from those in operation during the 1970s, when most of them had been directly attracted by SOEs to fund their operations and expansion, thereby deepening the ISI process.

During the Real Plan (1994-98), originally implemented to control the longlasting hyperinflationary process, the state sustained the strong overvaluation of the national currency (see fig. Al) and the associated current-account deficits by borrowing, directly and indirectly, foreign exchange from international financial markets. ${ }^{62}$ As had happened many times before, exchange rate overvaluation not only taxed exports, mostly raw or semiprocessed materials, and subsidized imports. It also reduced domestic primary commodity prices and strongly subsidized, and thus stimulated, the repatriation of profits by foreign-invested capitals, now structurally enlarged as the privatization of SOEs, timidly initiated during the previous period, accelerated. ${ }^{63}$ Allegedly market-distorting export taxes and state restrictions to primary commodity international trade were then phased out as forms of ground rent appropriation by social subjects other than landowners. In other words, under the ideological form of a monetary policy aimed at keeping inflation at check, in theory a requirement for the efficient allocation of resources, the Real Plan reinstated exchange rate overvaluation as the general form of ground rent appropriation by industrial capital and junior partners.

With the two main sources of extraordinary social wealth that had been sustaining capital's normal valorization in expansion, the local economy not only stabilized through 1994, when the Real Plan was launched, but also started growing strongly (see fig. A4). In this context, ex-dependency theorist Fernando

62. D. Dias Carneiro et al., "The Structure of Public Sector Debt in Brazil," Research Network Working Paper R-424 (Inter-American Development Bank, Washington, DC, 2001), 20; Carneiro, Desenvolvimento, 280-91; C. Lanzarini Casa, "Dívida interna (1994-2004): Preferência pela liquidez e estabilização via poupança externa," Revista Sociedade Brasileira de Economia Política 25 (2009): 74-103.

63. See A. Castelar Pinheiro, "The Brazilian Privatization Experience: What's Next?," Working Paper CBS-30-02 (Centre for Brazilian Studies, University of Oxford, 2002) on SOEs privatization during the 1990s. 
Cardoso, the "successful" minister of finance, had no difficulty in defeating PT's candidate, Lula da Silva, in the late-1994 presidential election on a ticket to continue with the "modernization" of the economy that was allegedly the reason behind the fall in the inflation rate and the return of growth after more than a decade of economic hardship. ${ }^{64}$ The problem, however, was that behind the transformations in its political forms of realization, the specific characteristic of the Brazilian process of capital accumulation remained unchanged, as limited and contradictory as ever.

Public debt was not the only source of foreign exchange-enlarging inflows during the 1990s, thus complementing ground rent in supporting capital's valorization. Funds raised through the sale of state assets at fire-sale prices were also important. These were mainly used to service the public external sector debt and thus reduce the financial requirements of the state. Under the argument that it was needed to root out the legacy of the old model of development from the new one, the 1988 constitution was reformed to end state monopolies in the provision of public utilities, and to allow for the participation of foreign capital in the privatization process. The program timidly initiated with heavy-industry SOEs during Collor's presidency was substantially extended under Cardoso's, to include companies at all levels of government. ${ }^{65}$

The privatizations of SOEs eliminated several of the earlier forms of ground rent transfer to industrial capital, because these would no longer sell their output and purchase their inputs at subsidized and inflated prices, respectively, or sustain an oversized workforce. Privatization also increased the demand for ground rent and its complementary sources of extraordinary wealth, as privatized firms began to compete for them. Not only were public utility prices substantially increased as companies entered the privatization process, but also the legal framework that regulated their operations moved significantly in favor of the new private owners. ${ }^{66}$ Hence, in terms of the process of capital accumulation through ground rent recovery, the privatization program was double edged. On one hand, and mainly in the short run, it generated resources that complemented the ground rent and the inflow of loanable capital in sustaining the profitability of

64. A. Spanakos and L. Renno, "Elections and Economic Turbulence in Brazil: Candidates, Voters, and Investors," Latin American Politics and Society 48 (2006): 1-26; L. Bethell and J. Nicolau, "Politics in Brazil, 1985-2002," in Bethell, Cambridge History of Latin America, 9:231-80.

65. J. Novelli and A. Galvaio, "The Political Economy of Neoliberalism in Brazil in the 1990s," International Journal of Political Economy 31 (2001-2): 3-52.

66. E. Amann and W. Baer, "The Changing Nature of Technological Dependence: Brazil's Public Utilities before and after Privatisation," Quarterly Review of Economics and Finance 41 (2001): 648. 
local industrial capital. On the other, the program increased the competition for these resources.

Between 1994 and 1998, the ground rent appropriated by social subjects other than landowners amounted to approximately 13 percent of all surplus value available for appropriation in the Brazilian economy, while the portion appropriated by industrial capital accounted for 31 percent of its profits (see fig. A5). During this period, net loanable capital inflows totaled 3 percent of all surplus value available for appropriation in the local economy, while funds collected through the privatization program approximated a further 6 percent of those surpluses. Half of these were disbursed by foreign investors and thus constituted a complement to the inflow of loanable capital to the Brazilian economy.

Nevertheless, though enlarged relative to the 1980s, the local ground rent and its complementary sources of extraordinary social wealth remained incapable of sustaining the pre-1980 scale of accumulation (i.e., a highly diversified and deepened industrial sector), not even when complemented with a third source of extraordinary surplus value, namely, the payment of most types of labor power below their value or full cost of reproduction. Large increases in labor productivity in the industrially advanced countries associated with the microelectronics revolution, and the continuous emergence of new sources of relatively cheap and disciplined/productive labor power performing automation-driven simplified tasks, greatly increased the requirement of ground rent by industrial capital in Brazil to sustain the relatively low level of labor productivity resulting from its specifically limited pattern of accumulation. ${ }^{67}$

Hence, the appropriation of ground rent by industrial capital became limited, crucially vis-à-vis previous periods. Effectively, partly reversing the radical 199094 liberalization experiment, market protection was restrengthened for some industrial branches, notably the final stages of value chains, while it was eliminated for others; without this protection industrial capital would have not been able to appropriate ground rent and valorize normally. The favored branches included the all-important assembly of motor vehicles, home appliances, and consumer electronics, and sections of the capital-goods industries. ${ }^{68}$ Industrial capital in these sectors and the privatized public utilities, which enjoyed a "natural" market pro-

67. On these global-market processes, see Iñigo Carrera, El Capital, 59-72; N. Grinberg, "The Political Economy of Brazilian (Latin American) and Korean (East Asian) Long-Term Development: Moving beyond Nation-Centred Approaches," New Political Economy 18 (2013): 171-97.

68. M. de Paiva Abreu, "The Brazilian Economy, 1994-2004: An Interim Assessment," in Bethel, Cambridge History of Latin America, 9:450. 
tection and lax regulatory framework, became landowners' main partners in the appropriation of the Brazilian ground rent. Specific subsidies and tax exemptions were added to the combination of exchange rate overvaluation and market protection as forms of ground rent recovery by industrial and "service" capital. For instance, foreign-controlled motor vehicles assembly, the leading industrial sector, benefited from a combination of the extended elimination of tariffs on auto-parts and machinery imports, which could be bought with an overvalued currency, and high market protection for their output. It also benefited from sharp cuts in production and consumption taxes and from generous subsidies and tax credits granted by local governments to fund investments. ${ }^{69}$

While market protection was eliminated for some industrial branches, commercial integration with the similarly structured Argentinian economy, which had slowly commenced in the late 1980s, accelerated through the creation of Mercosur. This process has liberalized intraregion trade for some sectors, while administering it for others (crucially, motor vehicles and auto parts), thus in practice enlarging domestic markets for those firms that have remained protected from extraregion competition. Industrial exports beyond these markets remained limited to semiprocessed raw materials or, generally, were possible only with state subsidies. ${ }^{70}$ Hence, the mixed character of Brazil's foreign trade policies during the 1990s: partial opening combined with integration under its leadership in a protected regional market. From the perspective of the global market, the country's economy continued participating in the international division of labor and the production of surplus value as a primary commodity producer, and hence as a source of ground rent for industrial capital.

The reduction of the ground rent relative to its requirement by industrial capital also resulted in the further dismantling, or restraining, of other political forms through which its appropriation had come about in the past, including the employment and payment conditions of public sector workers. As part of its effort to balance the budget, Cardoso's government fostered the downsizing of the state apparatus and the restructuring of the social-security system. For that purpose, it took advantage of an ongoing political and ideological campaign

69. M. Bede, "A politica automotive nos anos 90," in De JK and FHC: A reinvenção dos carros, ed. G. Arbix and M. Zilbovicius (São Paulo: Scritta, 1997), 357-87; A. Rodriguez Pose and G. Arbix, "Strategies of Waste: Bidding Wars in the Brazilian Automobile Sector," International Journal of Urban and Regional Research 25 (2001): 134-54.

70. W. Baer et al., "Economic Integration without Policy Coordination: The Case of MERCOSUR," Emerging Markets Review 3 (2002): 269-91; N. Grinberg, "Where Is Latin America Going? 'FTAA or '21st Century Socialism'?" Latin American Perspectives 37 (2010): 185-202. 
emphasizing the disparities between wages and retirement plans of public and private sector employees, and of the weakening of trade unions after a decadelong contraction in employment levels. ${ }^{71}$ Together with increases in the price of privatized public services, these policies also accelerated the process of differentiation of the productive attributes of the working class (the skills and concomitant conditions of reproduction), which resulted from the development of increasingly automated and computerized technologies. ${ }^{72}$

Hence, it now can be seen that neoliberalism and developmentalism have not been two fundamentally distinct political and ideological options. Rather, they have been two different historical forms of realization, mediations, of the Brazilian process of capital accumulation as it was reproduced under different objective conditions. The specificity of neoliberalism in Brazil, and thus the general characteristics of the ISI process during this period, has arisen from the following developments. First, the insufficiency of ground rent to sustain the previous scale of capital accumulation, which manifested itself in the partial dismantling of the system of market protection, the privatization of state assets, and cuts in state employment and investments. Second, the reestablishment of loanable capital inflows complementing ground rent in sustaining the limited process of valorization of industrial capital, which came about through capital-account opening. ${ }^{73}$ Third, the replacement of previously visible and "state-intensive" forms of ground rent appropriation, like export taxes, with invisible and politically acceptable forms, like exchange rate overvaluation, as the general modality of ground rent transfer to industrial capital. Moreover, as in the industrially advanced economies, neoliberalism in Brazil also expressed capital's necessity to increasingly differentiate the productive attributes of the different fragments of the collective worker of large-scale industry, resulting from the global-scale process of skillreplacing technical change associated with the computerization and robotization of industrial facilities.

On this weak basis, economic growth recovered, but was relatively poor by Brazilian long-term standards, averaging only 1.7 percent in per capita terms

71. J. Novelli and A. Galvaio, "The Political Economy of Neoliberalism in Brazil in the 1990s," International Journal of Political Economy 31 (2001-2): 23-29.

72. Iñigo Carrera, El Capital, 59-76; Grinberg, "Political Economy," 181-82.

73. Then, the profit-led regime of accumulation was not superseded by a finance-led regime, as argued in M. Bruno, H. Diawara, E. Araujo, A. Reis, and M. Rubens, "Finance-Led Growth Regime no Brasil: Estatuto teórico, evidências empíricas e consequências macroeconômicas," Revista de Economia Política 31, no. 5 (2011): 730-50. During this period, the inflow of loanable capital in the Brazilian economy remained a development (a support) of the process of accumulation of global industrial capital, the active subject of social reproduction. 
between 1995 and 1998. Industrial value-added contracted sharply during the entire period. The sector's participation in national output thus fell from 26 percent in 1993 to 14 percent in 1998 (see fig. A4). Investment rates were low even when compared with those prevailing during the 1980s, as large masses of industrial capital disappeared and privatized public utilities underinvested-except for the telecommunications industry, which was undergoing a rapid process of technological change. ${ }^{74}$ Between 1989 and 1999, wage labor employment fell by 3.2 million, with most of these jobs losses occurring in the industrial sector. The level of informality increased from 34 percent in 1989 to 41 percent in 1998, while the total unemployment rate in the metropolitan area of São Paulo, Brazil's industrial heartland, rose from 8.7 percent to 19.3 percent. This evolution of employment conditions weakened labor's bargaining power and resulted in sharp real-wage contractions. ${ }^{75}$ After dropping 37 percent between the peak of 1986 and 1991, real average wages in manufacturing fell a further 20 percent during 1992-98, thus expanding the mass of extraordinary surplus value arising from the payment of the labor force below its value (see fig. A3).

These developments resulted in the reshaping of class dynamics and political processes. First, as noted, the weakening of labor-market conditions associated with the limited reproduction of industrial capital, and the increase in skill-based differentiation, eroded the bases of working-class political strength. The trade union movement, contrary to that of the 1980s, became fragmented and focused on struggles that attempted to minimize losses. Second, the relative increase in the weight of loanable capital inflows in supporting capital accumulation came about through the expansion of the politico-economic space of those fractions of capital at the center of the process (i.e., banking or financial capital). Third, after a short period that kick-started the process (1990-92), the general political representation of capital accumulation during the period that consolidated neoliberalism fell in the hands of the right-of-center Brazilian Social Democratic Party (PSDB) - appealing largely to nonunionized, highly skilled wage laborers as well as to office workers-allied to the conservative Liberal Front Party (PFL).

The contradictions inherent to this limited form of capital accumulation became crudely evident as soon as its weak foundations eroded. Through the late

74. E. Amann and W. Baer, "Neoliberalism and Its Consequences in Brazil," Journal of Latin American Studies 34 (2002): 945-59; Novelli and Galvaio, "Political Economy of Neoliberalism," 26-27; M. Pochman, O emprego no desenvolvimento da nação (São Paulo: Boitempo, 2008), 55-56.

75. Amann and Baer, "Neoliberalism and Its Consequences," 955; Novelli and Galvaio, "Political Economy of Neoliberalism," 26-27; Pochman, O emprego, 59-79. 
1990s, a new contraction of global credit supply became apparent in the decline of world economic growth, and thus of the demand for raw materials and of Brazilian ground rent, and in the retrenchment of loanable capital flows to socalled emerging markets. Without these sources of extraordinary social wealth, the Brazilian economy experienced a new, profound crisis. Although growth improved somehow in the early 2000s, this was entirely based on a new strong wage squeeze and the short-lived undervaluation of the exchange rate that followed the phasing out of the Real Plan in January 1999. Effectively, real wages in manufacturing fell by a further 24 percent between 1998 and 2003 when they were only 37.5 percent of the 1986 peak value (see fig. A3). Exchange rate undervaluation, in turn, averaged 12.5 percent during 2001-3, helping protect the domestic market and expand industrial exports, and also generating a large inflow of direct foreign investments (see fig. Al).

E. WORKERS' PARTY GOVERNMENT AND THE SURGE OF

NEODEVELOPMENTALISM: POSTNEOLIBERALISM

OR INCLUSIVE NEOLIBERALISM? ${ }^{76}$

Through 2002, the global process of capital accumulation slowly began to recover, stimulated by record-low interest rates in the industrially advanced economies. Yet, when the presidential election was held in late 2002, the Brazilian economy was confronting a new currency crisis. Although this would begin to change afterward, the availability of credit for developing countries and primary commodity prices were still at their lowest levels in many years. As in 1994 and 1999 the candidates of the incumbent PSDB and the PT contended for the presidency. This time the context was markedly different. Cardoso's administration was highly compromised by the continuing fiscal adjustment program, the fall in real wages and the emerging crisis; it would have found it hard to continue in this direction without the backing of trade unions and grassroots movements. These were PT's main pillars. The political forms of realization of the process of capital accumulation thus changed, mediating the developments in its economic content. In the November elections, Lula Da Silva, the historic leader of the modern trade union movement, was elected president in his fourth attempt. The PT's electoral manifesto, however, was far less radical than the one it had defended when founded in 1980, at the highest point of the Brazilian process of capital accumulation through

76. This section develops and updates the analysis presented in Grinberg and Starosta (2014, 25159). 
ISI and in its previous failed attempts for the presidency. Indeed, when in the final stages of the campaign, Lula was blackmailed by the incumbent government, the mainstream press and the IMF to reassure his neoliberal credentials, he not only drastically softened his stance on economic policy but also wrote the infamous "Letter to the Brazilian People" in which he committed to honor Brazil's financial commitments and continue with the economic legacy left by the Cardoso administration. Lula also distanced himself from the most radical grassroots groups that had formed and supported the PT. And, to reassure the business sector of his intentions, he picked as his deputy a well-known business leader from the right-ofthe-center Liberal Party (PL). ${ }^{77}$

When it assumed power, the Lula administration fulfilled its latest campaign promises. With ground rent still at low levels and loanable capital outflows enlarging, the adjustment of the public sector budget went further than during Cardoso's second term. Because foreign lenders were not willing to fully refinance Brazil's external liabilities, most of which indirectly fell on the state, budget surpluses had to be expanded in order to genuinely pay an increasingly larger portion of the interest on the massive public debt. ${ }^{78}$

Yet, despite this negative outlook, economic growth soon accelerated to levels not experienced for a long time, averaging 5.4 percent in real terms during 200413, despite the global financial crisis (see fig. A4). Contrary to mainstream opinions, ${ }^{79}$ this strong recovery did not result from the market reforms implemented since the early 1990s. As we have seen, these mediated the limited reproduction of a process of capital accumulation with essentially unchanged specific characteristics. Nor did it simply result from contemporary improvements in the country's terms of trade as argued by radical critics. ${ }^{80}$ This alone could have not explained the relatively strong performance of the still domestic-market oriented industrial and service sectors. Without state policies supporting them, primary commodity price hikes would have simply resulted in an increase in the ground rent appropriated by landowners. Rather, the sharp recovery of international primary commodity prices, partly resulting from China's and India's ever-expanding demand for them and easy money-funded financial capital's bets that this would

\footnotetext{
77. Spanakos and Renno, "Elections," 15-20; Grinberg and Starosta, "From Global Capital Accumulation," 254.

78. A. Saad-Filho and L. Morais, "Lula and the Continuity of Neoliberalism in Brazil: Strategic Choice, Economic Imperative or Political Schizophrenia?," Historical Materialism 13 (2005): 19-20; Grinberg and Starosta, "From Global Capital Accumulation," 255.

79. See, e.g., Roett, "Reform"; Edwards, Left Behind.

80. See, e.g., J. Petras, "Crisis in Latin America," Latin American Perspectives 36 (2009): 192-213.
} 
never subdue, together with related output and productivity increases in the agrarian and, increasingly, mining and oil sectors, gave place to a solid expansion of Brazilian ground rent which manifested itself in a new set of state policies channeling it to industrial and service capital (see fig. A2). ${ }^{81}$

As had happened many times before, the exchange rate became increasingly overvalued, hence transforming a portion of the enlarged ground rent into capital's profits, especially through low-priced imports and profit remittances (see figs. Al, A5). The central bank portrayed these policies as a means of targeting inflation, which actually resulted from its own reserve accumulation strategy wherever purchases were not fully sterilized, and increasingly expansionary credit policies. This kept domestic interest rates at internationally high levels, even when liquidity and Brazil's creditworthiness were rising in global credit markets. As interest rates set by the Central Bank to control inflation also affect directly the return on public sector bonds, this policy attracted large sums of short-term capital to the public debt market. ${ }^{82}$ In practice, as in the 1990 s, the state borrowed foreign exchange indirectly, at internationally high interest rates, increased their supply and kept their domestic price low. In 2008, as primary commodity prices peaked, the Real reached the mid-1990s levels of overvaluation (as much as 85 percent), thereby channeling to social subjects other than landowners, largely industrial and service capitals, a portion of the expanding ground rent equal to 22 percent of all surplus value available for appropriation in the economy. ${ }^{83}$ By 2011 , as international primary commodity prices more than fully recovered from the 2009 slump, those percentages increased to 156 and 35 , respectively (see figs. A1, A2, A5).

The expansion of ground rent manifested itself in the expansion of the accumulation process, while industrial and "service" capital managed to appropriate directly a portion of the enlarged rent through exchange rate policies and lowpriced energy. It also resulted in an increase in state resources. A portion of ground rent was, in a first instance, appropriated by the state through import taxes paid with an overvalued currency. Second, the expansion of economic activity itself enlarged fiscal revenues in general. The government's broadly neoliberal first economic team was then partly replaced by more developmentalist

81. See Humberto Campodónico, Renta petrolera y minera en países seleccionados de América Latina (Santiago: CEPAL, 2008), 39-45, on the recent evolution of the Brazilian oil-extraction rent.

82. P. Arestis et al., "Inflation Targeting in Brazil," International Review of Applied Economics 25 (2011): 127-48; M Garcia, "Can Sterilized FX Purchases under Inflation Targeting Be Expansionary?," Stanford Center for International Development Working Paper 441 (2011).

83. Grinberg and Starosta, "From Global Capital Accumulation," 255-56. 
colleagues belonging to the PT's left wing. The party was perfectly suited to undertake the general political representation of the process of capital accumulation during a period of ground rent expansion-crucially, because it was allied, in government and congress, to business-friendly parties with which it somehow recreated the populist alliance of the 1950s. Nevertheless, state policy maintained a commitment to a strong and stable currency (the ideological euphemisms normally used to defend overvaluation), and former Bank of Boston president and PSDB politician Henrique Meirelles continued as head of the "independent" Central Bank. ${ }^{84}$

Economic policies thus became increasingly expansionist and began to regain some pre-neoliberal, developmentalist features, allegedly to sustain aggregate demand for local capital while solving supply-side market failures. Market protection was enhanced for industrial capital. Interest rates on state-bank loans were cut, while their supply to both producers and consumers expanded. Public sector expenditures grew strongly, including those on social security. ${ }^{85}$ The latter not only mediated the enlargement of the domestic markets but also helped reproduce a labor force with the attributes required by a rapidly expanding industrial capital and, more generally, created/reinforced the political conditions needed for the reproduction of the capital accumulation under its new economic forms. Moreover, in 2007, as the mass of ground rent available for appropriation expanded, the government launched phase 1 of the Growth Acceleration Program (phase 2 would be implemented in 2011) to improve, much like the first and second NDP during the 1970s, the provision of infrastructure. ${ }^{86}$ Foreign policies and international relations also recovered some of their past characteristics by means of a widely cheered new assertion of Brazil's international leadership and independent foreign policy, especially through its alliance with Mercosur partners and other large "global south" nations in rejecting US free-trade projects for the region. ${ }^{87}$ As usual, these were nothing other than political and ideological forms of realization of the expansion of the Brazilian ground rent and the limited process of

84. Ban, "Brazil's Liberal Neo-Developmentalism," 303-4.

85. A. Saad-Filho and L. Morais, "Brazil beyond Lula: Forging Ahead or Pausing for Breath?," Latin American Perspectives 38 (2011): 34-36.

86. G. Arbix and S. Martin, "Beyond Developmentalism and Market Fundamentalism in Brazil: Inclusionary State Activism without Statism" (paper presented at the workshop on "States, Development, and Global Governance," at the Global Legal Studies Center and the Center for World Affairs and the Global Economy [WAGE], University of Wisconsin-Madison, 2010).

87. Saad-Filho and Morais, "Brazil beyond Lula," 37; Ban, "Brazil's Liberal Neo-Developmentalism," 310. 
capital accumulation, crucially through the protection of the markets where capital realized the appropriation of ground rent. ${ }^{88}$

These politico-economic processes came about through changes in class dynamics. Working-class activism strengthened and trade union struggles became offensive, while mainstream sectors closed ranks in support of the PT government and radical elements splintered in left opposition to its policies. Yet, expressing the specific characteristics of the Brazilian process of capital accumulation, the trade unions' status as quasi-state organizations was reinforced, crucially as their leadership became increasingly incorporated into the structure of PT's government. ${ }^{89}$

Authors sympathetic to this set of policies have claimed that new or liberal (neo)developmentalism has been more than an improved version of old or statist developmentalism that keeps the rational kernel of neoliberal policies (stable monetary policy and outward orientation). Rather, they claim, these policies reposition the state in those sectors of the economy with positive externalities, where the market does not produce socially optimal amounts (infrastructure, education, producer credit, technology upgrading, etc.). ${ }^{90}$ Critics, on the contrary, have argued that such policies have merely furthered neoliberalism, albeit with more extended (clientelistic) social policies. ${ }^{91}$ But in fact, new or liberal (neo)developmentalism has been the politico-ideological form of realization of the fundamentally unchanged Brazilian process of capital accumulation in a period when the ground rent available for appropriation experienced a substantial expansion, crucially visà- vis the previous two decades, yet has been unable to sustain a process of industrial deepening of the sort that had occurred during the age of statist developmentalism (both populist and authoritarian). As skill-replacing technical changes were consolidated in large-scale industries, and manufacturing continued moving to East Asia in search of a relatively cheap and highly disciplined/productive workforce, it became no longer feasible for capital to develop a diversified industrial sector as a form of recovering ground rent in Brazil. Statist developmentalism thus lost its raison d'être. Indeed, although significantly enlarged, the Brazilian ground rent has been able to support only a relatively mild process of industrial development. In 2013, after ten years of solid economic growth, manufacturing valueadded was only slightly more than half of 1986 values (see fig. A4).

88. Grinberg, "Where Is Latin America Going?"; Grinberg and Starosta, "From Global Capital Accumulation," 256-57.

89. Antunes and Santana, "Dilemmas."

90. See, e.g., Arbix and Martin, "Beyond Developmentalism and Market Fundamentalism."

91. See, e.g., Petras, "Crisis." 
Despite that general trend, the recovery of the Brazilian ground rent gave place, largely through Vale's and Petrobras's purchases, to some industrial deepening in the form of the re emergence of various capital-goods and heavyengineering sectors, like the shipbuilding industry, that had collapsed during the 1990s. ${ }^{92}$ However, extra-Mercosur sales of industrial goods other than semiprocessed raw materials (i.e., other than rent-bearing commodities) has remained limited and, has generally been attached to bilateral agreements, as in the case of motor vehicles, or has been possible largely because of state subsidies, as in the case of airplanes. ${ }^{93}$

Under those relatively favorable conditions, employment growth accelerated, while real industrial wages increased strongly, yet by the early 2010s these wages remained 40 percent below the peak level of 1986. Moreover, economy-wide average wages failed to show any significant recovery throughout the PT governments and remained stagnant at 2003 levels, which were around 30 percent below that of 1997 and 50 percent below the level of 1986 (see fig. A3). ${ }^{94}$ Despite the progressive rhetoric and inclusive social policies, neodevelopmentalism has been powerless to end the payment of labor power below its value as a source of profitability, let alone to transform the economic structure of the Brazilian society. This has been evident in the recent reintroduction of orthodox economic policies while international primary commodity prices and the ground rent collapsed, and in the economic and political crises that ensued.

\section{CONCLUSION}

This article has analyzed the trajectory of the Brazilian economy from the period of old or statist developmentalism to the surge of new or liberal (neo) developmentalism, arguing that both kinds of developmentalism, old/statist and new/liberal, have been political and ideological forms of realization of a process of capital accumulation revolving around the appropriation of ground rent by different social subjects, crucially its recovery by industrial capital, rather than al-

92. Paschoalin, Brazil Shipyard Report 2012 (Rio de Janeiro: Paschoalin Consultoria, 2012).

93. Even Embraer's success should be seen with caution. The firm's international competitiveness has to a large extent resulted from the relatively low cost of its technical workforce and the credit subsidy granted to clients by the Brazilian state, which cover almost the total sale price of airplanes rather than the limited value added domestically. Indeed, unlike in other aircraft producing countries, it has led to relatively few positive spillovers, as the company has specialized in assembling imported parts. See P. Figuereido et al., "Risk Sharing Partnerships with Suppliers: The Case of Embraer," Journal of Technology Management of Innovation 3 (2008): 27-37.

94. M. Vernengo, "The Brazilian Economy after Lula: What to Expect?," CESifo Forum 12 (2011): 17-22, http://www.ifo.de/portal/pls/portal/docs/1/1201877.PDF. 
ternative policy options implemented by a (relatively or absolutely) autonomous state.

Despite variations across subperiods outlined above, old/statist developmentalism was the political form of realization of the Brazilian process of capital accumulation during a period characterized by the consolidation of foreign-owned industrial capital (MNC subsidiaries) as landowners' main partner in the appropriation of ground rent and by the latter's relatively strong growth. Conversely, new/liberal (neo)developmentalism has been the political form of realization of the Brazilian process of capital accumulation in a period when the ground rent available for appropriation experienced a substantial expansion, crucially vis-àvis the previous two decades, but nevertheless remained insufficient to sustain a major process of industrial deepening as had occurred during the age of old developmentalism-hence, its eclectic or hybrid characteristics (i.e., the combination of neoliberal and developmentalist policies).

More generally, through the analysis of the Brazilian experience, the article claims that changing economic policies (local and foreign) and international flows of money and commodities, as well as (geo)political processes through which these come about, are forms of realization of the process of capital accumulation on a global scale, whose material unity is established in the production of relative surplus value. Hence, the insights into the specific characteristics and long-term development of the Brazilian process of capital accumulation advanced here should also shed extra light on the developmental patterns of other national societies participating in the global economy as primary commodity producers, not only those of South America, as already analyzed elsewhere, ${ }^{95}$ but also beyond that region. The process of capital accumulation there has been similarly structured: also revolving around the recovery of the flow of surplus value in the form of ground rent resulting from their specific participation in the international division of labor. 


\section{APPENDIX}

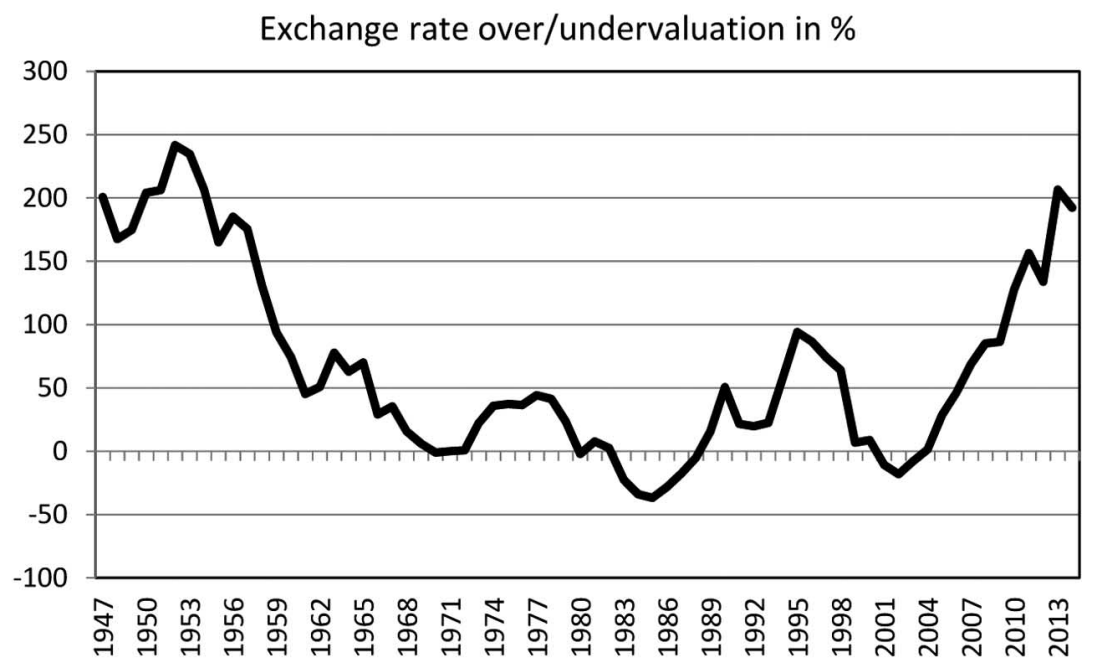

Figure A1. Sources: Grinberg, "Capital Accumulation and Ground-Rent," 458-59, and updates. Note: 100 = parity of exchange rate with US\$.

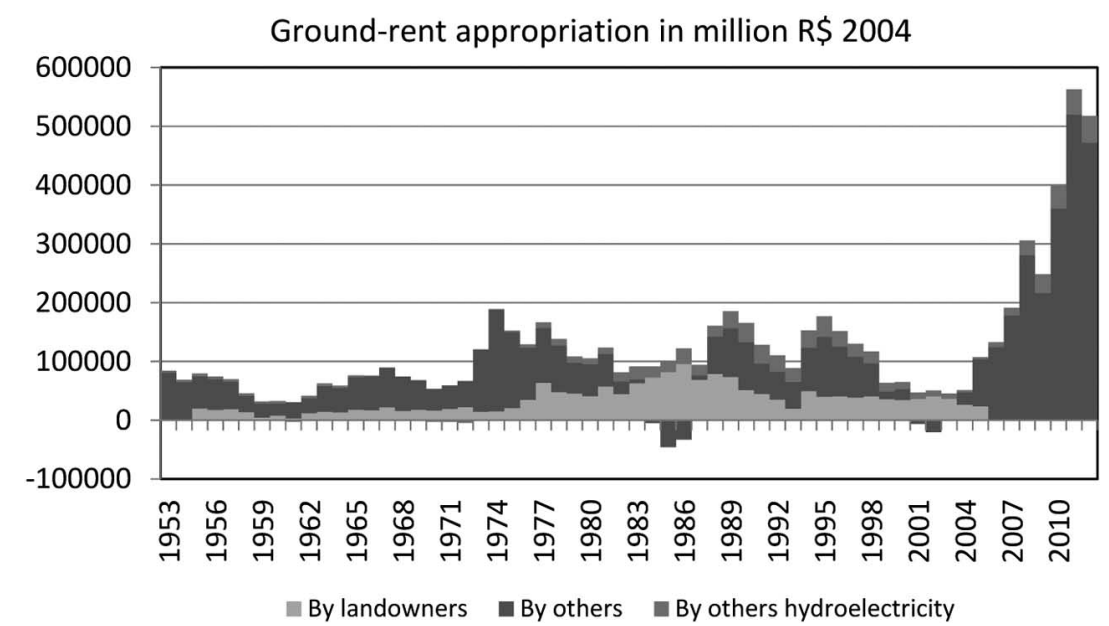

Figure A2. Sources: Grinberg, "Capital Accumulation and Ground-Rent," "On the Brazilian Ground Rent," and updates. Note: Time series of ground rent appropriated by (agrarian) landowners are for 1955-2005. "By others hydroelectricity" is the difference between local and US prices of electricity multiplied by the amount of hydroelectricity generated in Brazil. US prices are converted into local currency using parity exchange rates. 


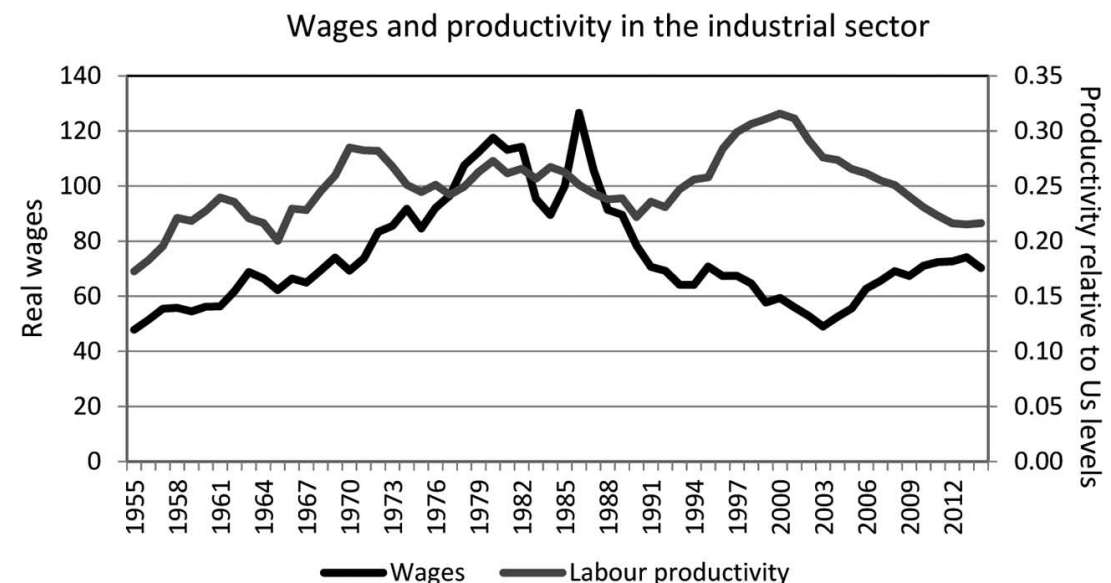

Figure A3. Sources: Grinberg, "Transformations," 204, "The Political Economy," 197, and updates. Note: Relative labor productivity is calculated for 2000 using parity exchange rates. The rest of the time series was computed using the relative evolution of output per manual worker.

GDP and industrial value-added in local currency of constant puchasing power $(1953=100)$

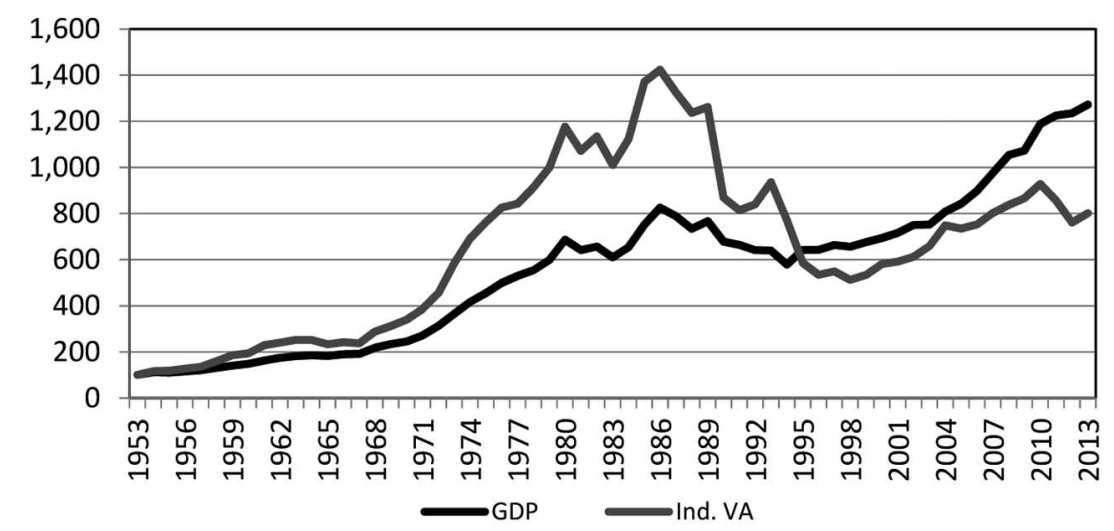

Figure A4. Sources: Grinberg, "Transformations," 106, "The Political Economy," 195, and updates. 
Ground-rent appropriated by others than landowners and net inflow of loanable capital as a portion of total surplus-value

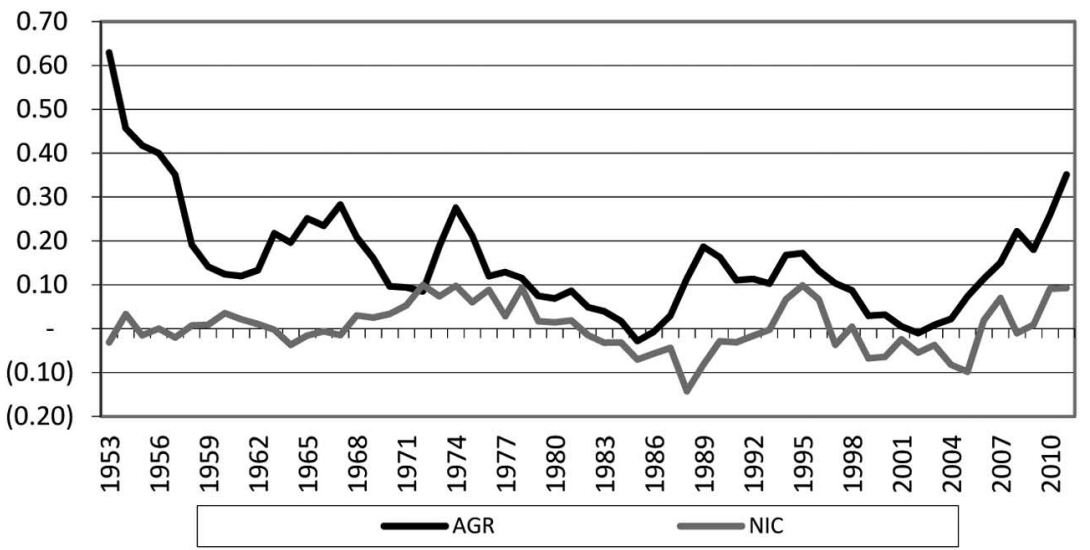

Figure A5. Sources: Grinberg, "Transformations," 101, "The Political Economy," 196, and updates. Note: $A G R=$ ground-rent appropriated by others than landowners; NIC = net inflow of loanable capital in the form of credit. 